\title{
Awareness and Adoption of Good Agricultural Practices among Smallholder Farmers in relation to the Adopted Villages programme: The Case Study of Northern Nigeria
}

\author{
Sennuga, S.O. ${ }^{1,2}$, Baines, R.N. ${ }^{1}$, Conway, J.S. ${ }^{1}$ and Angba, C.W ${ }^{1,3}$ \\ ${ }^{1}$ School of Agriculture food and Environment, Royal Agricultural University, Stroud Road, Cirencester, \\ Gloucestershire, United Kingdom, GL7 6JS \\ ${ }^{2}$ Federal Ministry of Agriculture and Rural Development, Abuja, Nigeria \\ ${ }^{3}$ Department of Agricultural Economics, University of Calabar, Nigeria \\ Corresponding Author Email: dr.yemisennuga@yahoo.co.uk
}

\begin{abstract}
:
This study assesses smallholder level of awareness and uptake of good agricultural practices (GAPS) that were initiated by the National Agricultural Extension and Research Liaison Services (NAERLS) in Nigeria; a programme to enhance the agricultural productivity and income of participants. This study engaged with 120 smallholder farmers and their extension officer and data were collected via structured face-to-face and livelihood questionnaires and then analyzed using descriptive and inferential statistics. The findings show that $82 \%$ of participants were aware of the specific GAPS covered by the NAERLS programme. Despite this, the majority of respondents were not practicing these. Participants identified numerous challenges to GAPS implementation, including; unreliable and inadequate rainfall; lack of farm inputs; high cost of farm inputs; lack of technical know-how; lack of irrigation facilities and high illiteracy. The study also shows that the level of awareness of GAPs among farmers in the study areas has a statistically significant impact on the productivity and livelihoods of smallholders. These initial results strongly suggest that the Nigerian government should provide funds to support NAERLS in order to intensify its intervention efforts. In the same vein, NGOs, rural developers, policy makers and government at all levels should be encouraged to provide farm inputs and credit facilities to farming communities to offset the high costs of inputs.
\end{abstract}

Keywords: Good Agricultural Practices, Awareness.

DOI: $10.7176 / \mathrm{JBAH} / 10-6-06$

Publication date:March $31^{\text {st }} 2020$

\section{Introduction}

Agriculture serves as a valuable source of income, contributing to poverty reduction and represents the main source of livelihood for 1.4 billion smallholder farmers and their families who produce nearly $70 \%$ of all food consumed worldwide (World Bank 2008; FAO 2010; Gahukar 2011; Lowder et al. 2014; Onyekwelu et al. 2015). Globally, there are approximately 2.5 billion people involved in full-or part-time smallholder agriculture, managing an estimated 500 million small farms (IFAD 2013). The agriculture sector is also the mainstay of the economies of most of the developing world. Furthermore in Sub-Saharan Africa an estimated $75 \%$ of resource-poor people rely on agriculture for their livelihoods, the sectoremploys about $60 \%$ of the workforce and contributes an average of $30 \%$ to Gross Domestic Product (GDP) (FAO 2010; Kalungu et al. 2013; Chowa et al. 2013). It is estimated that nearly $70 \%$ of the people in developing countries live in rural areas where agriculture is the main source of livelihood, and there are some 36 million smallholder farmers across the continent of Africa (Vermeulen et al. 2012; Kalungu et al. 2013; Wright et al. 2014).

By definition smallholder farmers cultivate small areasof land, often less than two hectares (ha), using family labour and simple technologies (e.g. mainly hand-held hoes, minimal use of animal traction and no tractors). Indeed, they are faced with several challenges including: lack of fertilizers; inadequate and unreliable rainfall; high cost of farm inputs; extremepoverty;inadequate finance; chronic illiteracy; poor storage and market prices and high rate of pest and disease attacks. Land scarcity, increasing population pressure, poorly targeted agricultural policies and agricultural management strategies exacerbate the problem (Nkala et al. 2011) while the rural population often depend on their agricultural production as their main source of both food security and income generation (Nagayets 2005; Umar et al. 2012).

In Nigeria, agriculture contributes about $42 \%$ to the GDP, employs $70 \%$ of the active population (Arokoyo 2005; Sennuga 2012; Osebeyo and Aye 2014) and produces $80 \%$ of food needed to feed the growing population (Nwafor 2008; Yila and Thapa 2008). Smallholder farmers are the backbone of agricultural production in 
Nigeria with over $90 \%$ of the agricultural output is derived from resource-poor farming, carried out by smallholder farmers ( $<3$ hectres) who have been the principal source of the national food supply for many decades (Adedipe et al. 2004).

Agriculture was a very important sector in the Nigerian economy in the 1960s; and the country was generally self-sufficient in food production, employment and exchange earnings. The situation is effectively the same three decades later with the exception that it is no longer the most important foreign exchange earner, a role now being played by oil industry.

However, the agricultural sector has significantly underperformed and experienced a serious decline over the last 40 years due to high revenue from the oil boom deflecting government attention with revenues underpinning other developments; as a result agriculture has fallen from about $75 \%$ of total export earnings in the 1960 s to less than 5\% (FGN 2008). Despite this sharp drop, agriculture is still the principal source of raw materials for the nation's agro-based industries and accounts for almost 88\% of non-oil export earnings (Oji-Okoro 2011; Osebeyo and Aye 2014). This reality has become clearly manifested in the high cost of food nationwide and food insecurity, both at the household and national level along with increasing malnutrition among children (Ansuya et al. 2018).

Overcoming the increasing incidence of chronic disease and the widespread problem of food security and rural poverty in Nigeria is one of the fundamental challenges confronting the Nigerian government and international agencies. The problem is mainly caused by the inaccessibility of resource-poor farmers to improved technologies emanating from the National Agricultural Research Institutes (NARIs) (World Bank 2012; Akinola et al. 2013). This is because improved technologies can only be beneficial to the end-users when judiciously put to use. However, many technologies developed by the research institutions in Nigeria have remained underutilized because the extension services, which are supposed to facilitate the dissemination of research-based information, have remained redundant and ineffective (Aker 2012). Further, the ratio of extension agent to farming families is now 1:3000 in Nigeria (FMARD 2005). Consequently, in an attempt to address this the "Adopted Village Concept" pilot project was introduced in 1996, under the World Bank, Assisted Programme of National Agricultural Research Project (NARP). However, following the collapse of the NARP in 1999 (Mustapha et al. 2012), the Agricultural Research Council of Nigeria (ARCN) issued a directive to the NARIs in 2008 to revisit and revive the earlier introduced concept of 'Adopted Villages' with a renewed vigour, culminating in the take-off of the 'Adopted villages' in 2009 (Akinola et al. 2013).

\subsection{The Adopted Village Concept}

According to Mustapha et al. (2012), the ARCN issued directive stated that each research institute, university, and college of agriculture was expected to identify two communities/high schools within its jurisdiction and mandate areas within which to promote best farming practices and government policies. In accordance with the directive, each institute is expected to identify farmers and engage them in a participatory rural approach using their farmland or field as a 'showroom' for the other community members to demonstrate a particular technology. The National Agricultural Extension and Research Liaison Services (NAERLS) of the Ahmadu Bello University, ABU Zaria has been working is 5 geographical zones of the country but with a particular emphasis on villages in the North West zone of Nigeria, in Kaduna and Katsina States.

The 'Adopted Village' concept is an extension approach aimed at enhancing the agricultural productivity and general livelihood of the rural dwellers in an integrated manner, focusing on health, education drinking water supply and so on. Demonstrations are conducted in each Adopted Village to encourage adoption of new technologies/practices among farmers. The principal aims of the 'Adopted Village' concept is to empower resource-poor farmers,enhance the economic and livelihood status of the beneficiaries' households, increase food security and market competitiveness, create job opportunities for youths and develop agriculture as a business and vacation.

The main objective of the 'Adopted Village' concept is to encourage large-scale adoption of improved technologies, economic empowerment of resource-poor farmers, create job opportunities for youths and ensure food security. Specifically, the 'Adopted Villages' concept is to:

- Create awareness in the rural areas and improve farmer's organizations development via communities' activities

- Empowerment of the communities through the initial provision of some facilities and infrastructural development in the village.

- Facilitate the transfer and adoption of improved agricultural technologies in the adopted villages. 
- Accelerate union and integration of differs programs of state/local government and other development agencies in the villages.

- Improve the economic status of the villagers through capacity building of the rural dwellers and communities.

- Enhance socio-economic status and livelihoods of the farmers with the provision of credit facilities for all farming families in the adopted villages.

- Operate an agricultural research outreach center including research-based information flow.

- Ensure adequate monitoring of the progress of the implementation of the project in the villages.

- Build vibrant rural communities that are productive, self-sustaining and create new markets.

The Adopted Village concept was initiated to speed up and upscale technologies adoption under the farmers' environmental condition in a participatory rural approach. The involvement of farmers in the concept is additional advantages which in turn facilitates the rate of adoption and boost the agricultural productivity of the participants. One of the villages in this case study is an adopted village (Sakadadi) while the other (Nasarawan Buhari) is not.

\subsection{Good Agricultural Practices (GAPs)}

GAPs are a collection of practices for on-farm production and post-production processes, resulting in safe and healthy food and non-food agricultural products while taking into account economic, social and environmental sustainability (FAO 2010; Lefebvre et al. 2015). GAPs cover a range of areas including maintaining soil fertility, water resource and irrigation management, cropland management, degraded land restoration, animal production and welfare, integrated pest management, integrated fertilizer management and conservation agriculture (Montagn et al. 2007; FAO 2010). GAPs explicitly aim to increase the supply of safe and high-quality food by promoting more sustainable crop production (Ali 2014) while also helping to improve market access and farmers' livelihoods (Poole and Lynch 2003; FAO 2010). Although GAPs have the potential to play a significant role in improving agricultural practices, there is currently limited empirical evidence on the level of awareness and implementation of GAPs. Therefore, this study aims to assess the effect of interventions on the livelihood and productivity of resource-poor farmers. The specific objectives of this study are to:

(i) examine the level of awareness of GAPs among smallholder farmers in the selected villages, one under adopt a village and one that is not;

(ii) explore the sources of information for the selected GAPs; and,

(iii) examine the extent of the implementation of GAPs technologies.

\section{Materials and methods}

\subsection{The study area and data description}

The study area comprises two Local Government Areas of Giwa and Sabon Gari in Kaduna State which are located in the Northern Guinea Savannah ecological zone of Nigeria (see Figure 1). These LGA were purposively selected based on the location of adopted villages concept initiated by NAERLS.

Giwa Local Government Area is located in the plain of the Northern part of Kaduna State. Giwa has eleven districts and twelve political wards. It lies between latitude $12.20^{\circ} \mathrm{N}$ to $12.52^{\circ} \mathrm{N}$ and longitude $7.0^{\circ} \mathrm{E}$ to $7.5^{\circ} \mathrm{E}$ (Oyakhilomen 2012). Giwa Local Government has an estimated population of 32,255 and is made up of Hausa/Fulani tribe with a population growth rate of $3.2 \%$ per annum, occupying $2145.79 \mathrm{sq} \mathrm{km}$ of land (National Population Commission-NPC 2006; Akinola et al. 2013). The vegetation of the area is mostly grasses and shrubs. The major crops grown in the area are maize, cowpea, tomatoes, sorghum, groundnut, pepper, onions, wheat and sugarcane.

Sabon Gari Local Government Area has six districts and eleven wards with a population of 734, 391. The population of the area is more diverse as it is predominantly made of settlers and non-indigenes that came to settle in Zaria for diverse reasons and due to numerous government institutions and amenities in the area. The local government is the home of several tertiary institutions and research institutes including; Ahmadu Bello University, Zaria, School of Aviation, Leather Research Institute, military college, and barracks (Akinola et al. 2013). Sabon Gari occupies a total of $273,779 \mathrm{sq} \mathrm{km}$ of land (NPC, 2006) laying at the border of Kaduna State. The major crops grown in the area are sorghum, cowpea, millet, soybean, rice, groundnut, amaranthus, cotton and carrot.

\subsection{Sampling procedure of the study area}

A multi-stage purposive and stratified random sampling procedure was followed for the selection of the study area. The study was confined to Kaduna State, Northern Nigeria (see Figure 1). A separate list of the LGA and 
Adopted Villages from Kaduna State was collected from NAERLS, Ahmadu Bello University, Zaria for the selection of the villages for the study (Table 1). Thus, two villages which participated in the Adopted Village Concept and sufficiently close to municipal, state or federal roads to enable a series of visits by the researcher were selected using a simple random sampling technique.

Both villages are situated in the Northern Guinea Savannah ecological zone. The rainy season lasts for about five months and the dry season for seven months. Agriculture is the principal economic activity and livelihood of about $90 \%$ of the population in both communities, and the bulk of agriculture is undertaken by men as cultural traditions do not permit women to actively engage in farming activities or own land. The women shell and extract groundnut oil using local methods for sale the while Fulani tribe extract milk from cows. Prominent traditional male activities include; blacksmithing, pottery, hunting and leather work. The major religions in the study area are Islam and Christianity, with about $90 \%$ of the population actively practicing Islam, yet living in a traditional polygamous family setting.

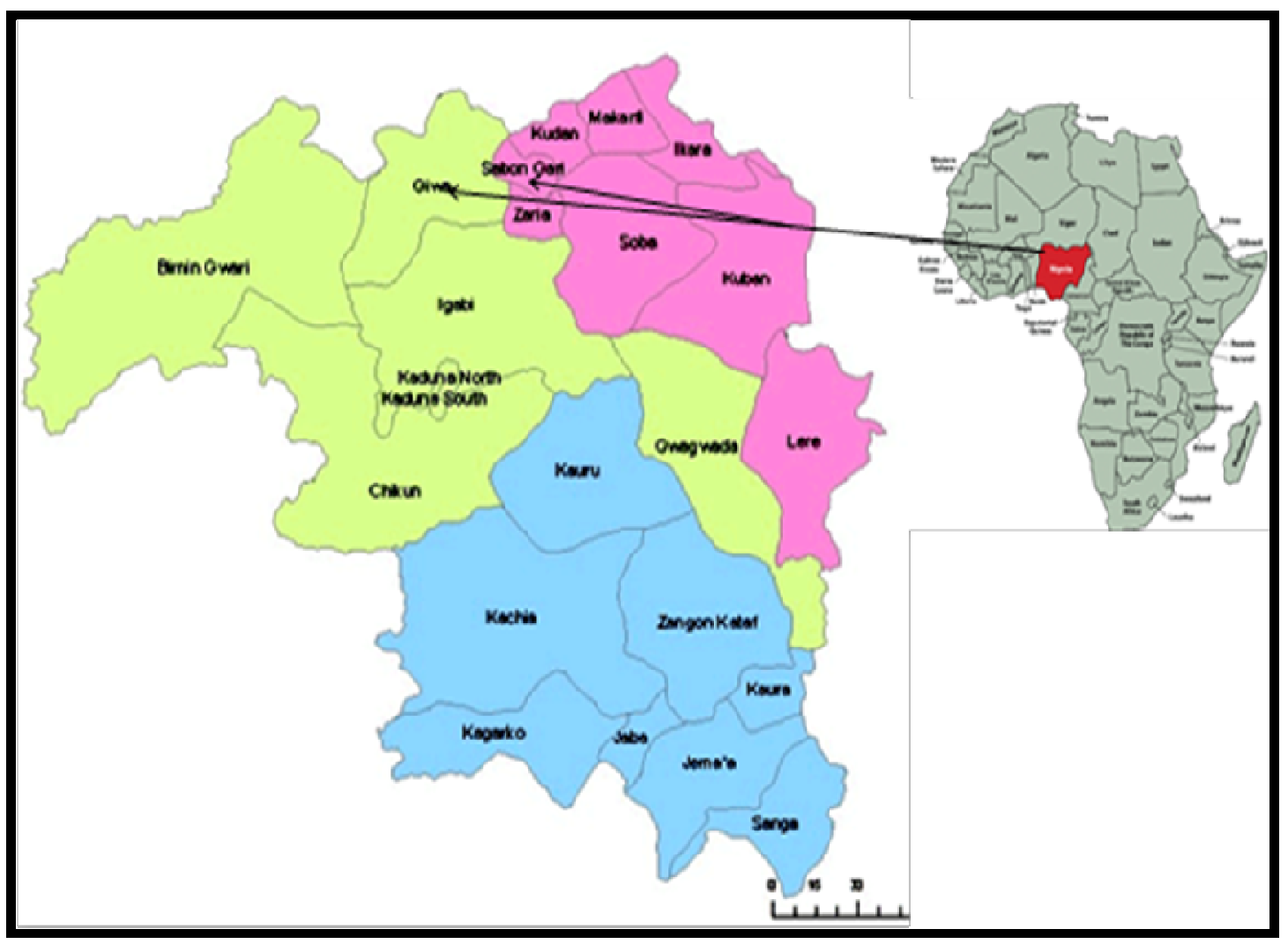

Fig. 1: Map of the Study Area showing Giwa and Sabon Gari Local Government, Kaduna State, Nigeria. 
Table 1: Villages in Kaduna and Katsina, North West Zone, Nigeria. Note: Those in bold are adopted villages while Nasarawan Buhari and Sakadadi are the case study villages for this research.

\begin{tabular}{|lllll|}
\hline $\mathbf{S} / \mathbf{N}$ & State & LGA & Village & Number \\
\hline $\mathbf{1}$ & $\begin{array}{l}\text { Kaduna } \\
\text { State }\end{array}$ & Zaria & Kufena & 150 \\
\hline $\mathbf{2}$ & & Giwa & Nasarawan Buhari & 250 \\
\hline $\mathbf{3}$ & & Giwa & Yansarki & 150 \\
\hline $\mathbf{4}$ & Giwa & Maigamo & 200 \\
\hline $\mathbf{5}$ & & Giwa & Hayingada & 75 \\
\hline $\mathbf{6}$ & & SabonGari & Hayindogo & 75 \\
\hline $\mathbf{7}$ & & SabonGari & Sakadadi & 250 \\
\hline $\mathbf{8}$ & & SabonGari & Hayin Sambo & 75 \\
\hline $\mathbf{9}$ & & SabonGari & Basawa & 75 \\
\hline $\mathbf{1 0}$ & & SabonGari & Maiwasa & 50 \\
\hline $\mathbf{1 1}$ & $\begin{array}{l}\text { Katsina } \\
\text { State }\end{array}$ & Danja & Kokami & 200 \\
\hline $\mathbf{1 2}$ & & Funtua & Tudun-Iya & 800 \\
\hline
\end{tabular}

\subsection{Selection of respondents}

From each village, a total of 60 arable farmers were selected using a stratified sampling procedure where the main rationale and criterion for choice of the participants were based on their participation and non-participation in the Adopted Village Concept, their age, gender, and farming experience. Thus, the total number of respondents interviewed for the study was 120 farming households. The participants were for Kaduna and Kastina States from Northern Nigeria.

\subsection{Data Collection and Analysis}

Data for this study were collected through household livelihood survey tool via face-to-face interviews conducted by the researcher. Prior to data collection, village group meetings were conducted in the LGA primary school in Giwa and Sabon Gari to introduce the project and its benefits to the villagers. The villagers were encourage to attend the meeting by the village head, and two buses were provided to convey the villagers to the meeting venue, 118 villagers attended from Nasarawan Buhari while 114 villagers present from Sakadadi village respectively. The farmers were contacted in their homes.

Household livelihood data were collected along with questions based on the study objectives as follows:

- The first section sought information on demographic characteristics of the smallholder farmers. Respondents were asked to indicate their age, the level of education attained, household education, the number of years in farming, the size of landholding (number of hectares owned and hectares rented).

- The second section considered the level of awareness of certain GAPs, with a specific focus on crop land management; soil fertility managements; water management; degraded land restoration; integrated pest management; crop selection and seedling. The rationale for the choice of GAPs was based on the modern farming practice being promoted by the adopted village concept and relevant to the agroclimatic conditions in the region. Respondents were asked to indicate their awareness using a 4-point Likert scale of "highly aware" (3), "Aware" (2) "Remotely aware" (1) and "not aware" (0).

- The third section addressed the farmers' sources of information for the specified GAPs. The respondents were asked to indicate their sources of information, choosing from extension agents, radio, mobile phones, television, newspaper, field day, agro-dealer, brochure and other farmers, among others.

- The level of implementation of the specified GAPs on the respondents' farmland was the focus of the fourth section. Respondents were asked to state level of implementation, using 5-point Likert scale of 
"very high" (4), "high" (3), "moderate" (2), "low" (1) and not at all (0). Respondent were also asked about the regularity to extension visit to their area, using a 6-point Likert scale of "yearly" (5), "three times a year" (4), "twice a year" (3), once a month (2), "during raining season" (1) and "no extension visit" $(0)$.

- The fifth section addressed prevailing problems confronting respondent in implementing the GAPs. The respondents were asked about factors such as lack of fertilizers, inadequate finance/capital, poverty, inadequate and unreliable rainfall, among others.

- The primary data collected using the survey were first edited by sorting through the questionnaire papers visually and discarding those with obvious anomalies such as non-response, multiple errors, and numerous missing data. The statistical package SPSS version 24 was employed for the analysis of the data. This paper mainly reports the descriptive analysis of the baseline conditions of the two communities

\section{Results and Discussion \\ 3.1 Respondents characteristics}

All the respondents were males; this is because the cultural traditions of the study area do not allow females to be actively involved in farming activities; furthermore, analysis of the two villages did not reveal any significant differences between the communities other than whether they were an adopted village or not (see section where you discuss extension) As a result the two communities will be described as one larger community in terms of household profiles.

Almost one-third (31\%) of the respondents were between 31-40 years old followed by $27 \%$ who were between 41-50 years old; in terms of new entrants to smallholding, just under 20\% were between 20 and 30 years old (Table 2). An overwhelming majority (97\%) of the respondents was married with half of these households having 10 or fewer members, the remainder had larger families of 21 plus members reflecting polygamy within the communities.

In terms of education of household heads some two thirds had no education or only primary education, about one quarter had secondary education and only some $8 \%$ had tertiary education (Table 2 ). When family education is considered there is evidence of investment in the next generation with less than $4 \%$ having no education (probably babies and infants), 55\% having primary education and $36 \%$ going on to secondary education (Table 2).

In relation to family income, $40 \%$ were in the income range of $\$ 301,000$ - $\$ 400,999$ (equivalent to $\$ 860$ $\$ 1,145$ ) followed by $24 \%$ who were in the range of $\$ 121,000$ - $\$ 300,999$ (i.e. $\$ 347-\$ 859$ ). This is less than $\$ 1.5$ per day poverty line i.e. income divided by number of adults. In the same vein, the family labour hired was $10 \%$. 
Table 2: Demographic representation of the socio-economic Characteristics of the smallholder farmers $(n=120)$

\begin{tabular}{ll}
\hline Variables & Percentage \\
\hline Age (years) & \\
$20-30$ & 15.8 \\
$31-40$ & 31.7 \\
$41-50$ & 27.5 \\
$51-60$ & 17.5 \\
$61-70$ & 6.7 \\
$>70$ & .8 \\
Gender (Sex) & \\
Male & 100 \\
Female & 0 \\
Marital status & \\
Single & 3.3 \\
Married & 96.7 \\
Household size & \\
10 & 50.8 \\
$11-20$ & 36.4 \\
$21-30$ & 12.1 \\
>31 & .7 \\
Level of education & \\
No education & 25.8 \\
Primary & 40.0 \\
Secondary & 26.7 \\
Tertiary & 7.5 \\
Family education & \\
No education & 3.3 \\
Primary & 55.0 \\
Secondary & 35.8 \\
Nertiary & 2.5 \\
\hline & 3.3 \\
\hline
\end{tabular}

\subsection{Awareness of GAPs among Smallholder Farmers}

This section will examine the results of the survey relating to the awareness and implementation as part of the Adopted Village project, more specifically: cropland management; water management; degraded land restoration; integrated pest management; crop and seed selection and crop and soil fertility management.

\subsection{Awareness of GAPs}

The data presented in Figure 2 indicates that $46 \%$ of the farmers are not aware of water management practices while $57 \%$ of the respondent indicated that they were aware of the use of irrigation and $23 \%$ stated that they were highly aware. $44 \%$ indicated that they were not aware of terracing and only $7 \%$ of respondents indicated they were highly aware. By implication, this shows that farmers in the adopted villages are aware of water management practices.

The data shown in table 2 reveal that majority of the respondents (95\%) were highly aware of fertilizer application while no respondents state that they were unaware. Similarly, the results show that a reasonable amount of the respondents (58\%) were aware of the use of manure while about $7 \%$ were unaware. A little above half of the respondents (52\%) indicated they were aware of cover cropping while $11 \%$ were unaware. Also, the level of respondents' awareness of intercropping was relative high with only $6.4 \%$ of respondents stating that they were not aware of the practice. 
Table 2: Distribution of respondents according to their level of awareness of GAPs

\begin{tabular}{|c|c|c|c|c|c|}
\hline $\begin{array}{l}\text { Agricultural } \\
\text { Production } \\
\text { Components }\end{array}$ & $\begin{array}{l}\text { Current } \\
\text { Practices }\end{array}$ & $\begin{array}{c}\text { Highly } \\
\text { Aware } \\
\%\end{array}$ & $\begin{array}{c}\text { Awar } \\
\%\end{array}$ & $\begin{array}{c}\text { Remot } \\
\text { Aware } \\
\text { \% }\end{array}$ & $\begin{array}{l}\text { Not } \\
\text { Aware } \\
\%\end{array}$ \\
\hline Crop land & Crop types & 23.6 & 61.4 & 7.1 & 7.9 \\
\hline \multirow[t]{2}{*}{ Management } & Cropping Systems & 21.4 & 63.0 & 6.4 & 9.2 \\
\hline & Tillage Systems & 22.9 & 60.0 & 10.0 & 7.1 \\
\hline Water & Use of Irrigation & 13.6 & 57.1 & 18.6 & 10.7 \\
\hline \multirow[t]{3}{*}{ Management } & Bunds & 7.8 & 20.2 & 26.0 & 46.1 \\
\hline & Mulch & 5.7 & 23.3 & 30.0 & 41.0 \\
\hline & Terracing & 7.2 & 21.2 & 27.4 & 44.3 \\
\hline \multirow[t]{2}{*}{ Restoration } & Re-vegetation & 14.0 & 20.2 & 42.2 & 23.6 \\
\hline & Crop Rotation & 18.6 & 57.1 & 19.0 & 5.3 \\
\hline Integrated & Use of Pesticides 20.0 & 56.0 & 15.0 & 8.3 & \\
\hline Pest & Tilling & 16.4 & 52.3 & 20.4 & 10.7 \\
\hline \multirow[t]{3}{*}{ Management } & Resistant Varieties & 14.3 & 55.0 & 17.9 & 13.1 \\
\hline & $\begin{array}{l}\text { Plot Selection } \\
\text { and Lavout }\end{array}$ & 159 & 571 & 143 & 120 \\
\hline & Planting Date & $\begin{array}{l}15.9 \\
19.3\end{array}$ & 57.1 & $\begin{array}{l}14.3 \\
20.0\end{array}$ & 3.6 \\
\hline Seeds, Crop & Sowing facility & 10.7 & 24.3 & 50.8 & 14.3 \\
\hline Selection & Sowing Depths & 12.9 & 45.7 & 26.4 & 15.0 \\
\hline and & Seed Dressing & 10.3 & 12.3 & 25.3 & 52.1 \\
\hline \multirow[t]{4}{*}{ Seedling } & $\begin{array}{l}\text { Seed Requirement } \\
\text { Re-planting }\end{array}$ & 13.6 & 50.0 & 25.0 & 11.4 \\
\hline & Local seeds & 11.4 & 50.7 & 25.0 & 12.9 \\
\hline & Use of manure & 22.9 & 58.0 & 12.1 & 7.1 \\
\hline & Mulching & 21.4 & 19.3 & 47.1 & 12.1 \\
\hline Soil Fertility & Fertilizer application & 95.1 & 13.0 & 2.1 & 0 \\
\hline \multirow[t]{2}{*}{ Management } & Cover cropping & 29.3 & 52.2 & 7.2 & 11.4 \\
\hline & Intercropping & 27.1 & 54.1 & 12.4 & 6.4 \\
\hline
\end{tabular}

\subsection{Sources of information for Good Agricultural Practices}

The sources and availability information have been argued to be critical factors affecting adoption rates of technologies (Oladele 2010). Additionally, Roger (2003) reported that extension officers play a positive and fundamental role in diffusing agricultural innovations from research to farmers. Moreover, dissemination of adequate and relevant information to smallholder farmers has been shown to enhance productivity and make more farm produce available all year round (Okunade 2006).

In order to gain a better understanding of whether these factors may influence respondents' level of awareness of the stated GAPs, the survey asked where respondents source information from. Overall, the majority of the participants considered extension officers' from NAERLS, as their main source of information on a range of GAPs. Although to a lesser extent, the radio was also noted as an important source of information, followed by mobile phones (Figure 3). Far fewer participants reflected other sources of information such as television, other farmers, and newspapers to be important information. The findings revealed that the majority of participants consider agricultural extension agents to be their most reliable and dependable source of accurate information.

However, the study showed that the non-participants considered farmer-to-farmers extremely useful in the farming business (see figure 4). In addition they also find revealed that radio is making significant contribution. From the survey we can conclude that farmer-to-farmer extension model is making remarkable different among the smallholder farmers.

On the other hand, a study conducted among maize farmers in Nigeria, Fadiji et al. (2005) found extension agents to be a major source of agricultural technologies and research based information dissemination to farmers. Findings show that the Adopted Village project was relatively effective and impacted the respondents, because the government extension agents are not consistent with the delivery of their work 
perhaps because of the extension ratio in Nigeria, 1:3000; not only in creating awareness but also in demonstrating the technologies on the village farms. This corroborates the findings of Akinola et al (2013), who found that the adopted village project improved the extension-rural household linkages, enhanced participants' capacity and improved their income and livelihoods within the community. The majority of the respondents who actively participated in the project were enlightened about better farming practices and other agricultural technologies.

The positive outcomes above could have potentially been possible without the Adopted Village Concept. However, it is important to note that the project was not without its own challenges such as lack of definite extension system, lack of reliable data, absence of reliable mobility, limited funds, unreliable internet connectivity for website and difficulty in identifying friendly and willing media houses and other available dissemination channel outfits (NAERLS 2011). These challenges had an effect on the survey, in that respondents had difficulty in recalling information as small scale farmers do not keep records of their expenditure and costs. Similarly, some respondents with large farms failed to keep interview appointments with the research team, after all, the arrangement had been made. Moreover, inaccessible roads to the remote farms and villages also presented difficulties, as many of the roads were extremely bad.

Figure 3: Distribution of Participants according to the sources of information on GAPs (Sakadadi Village)

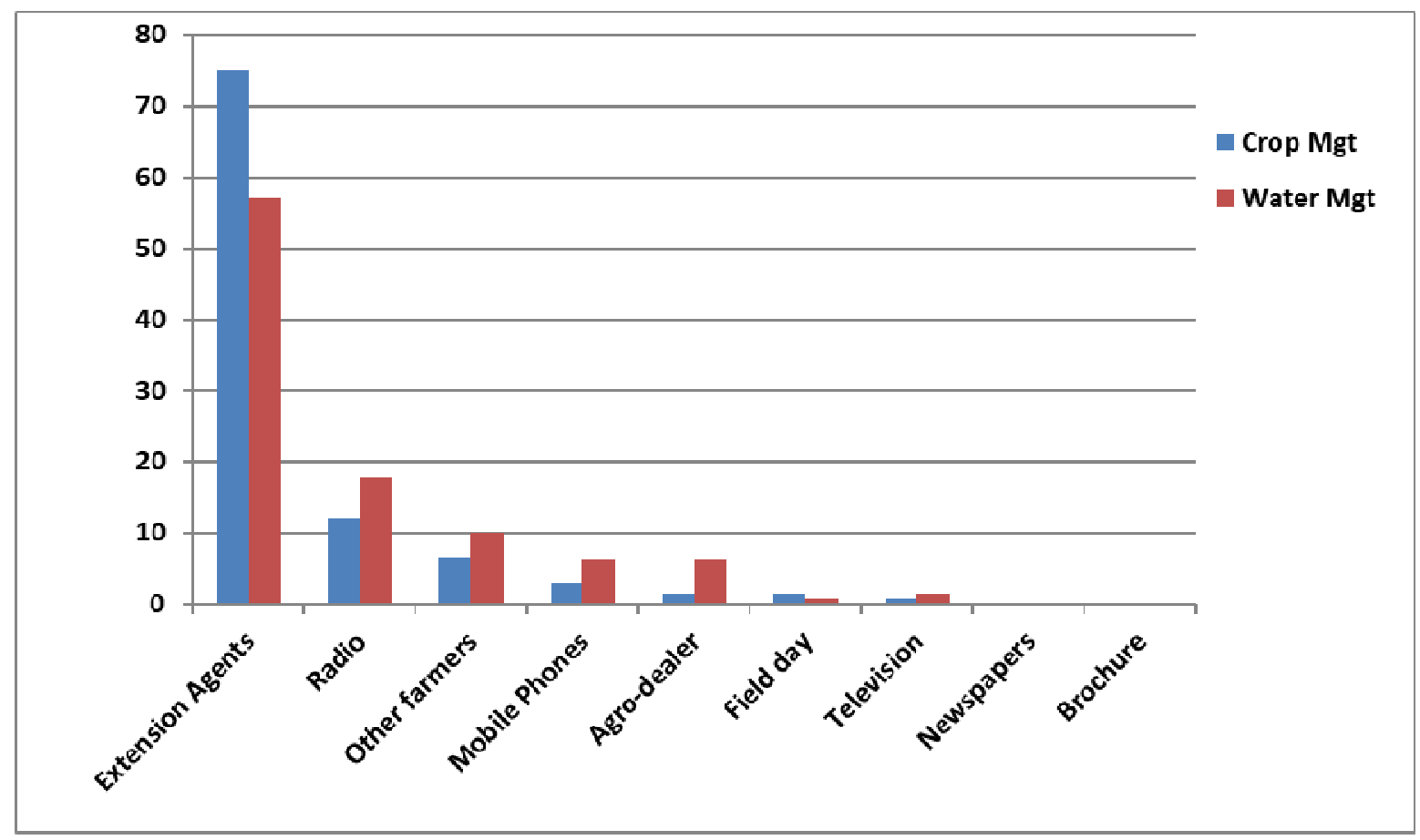




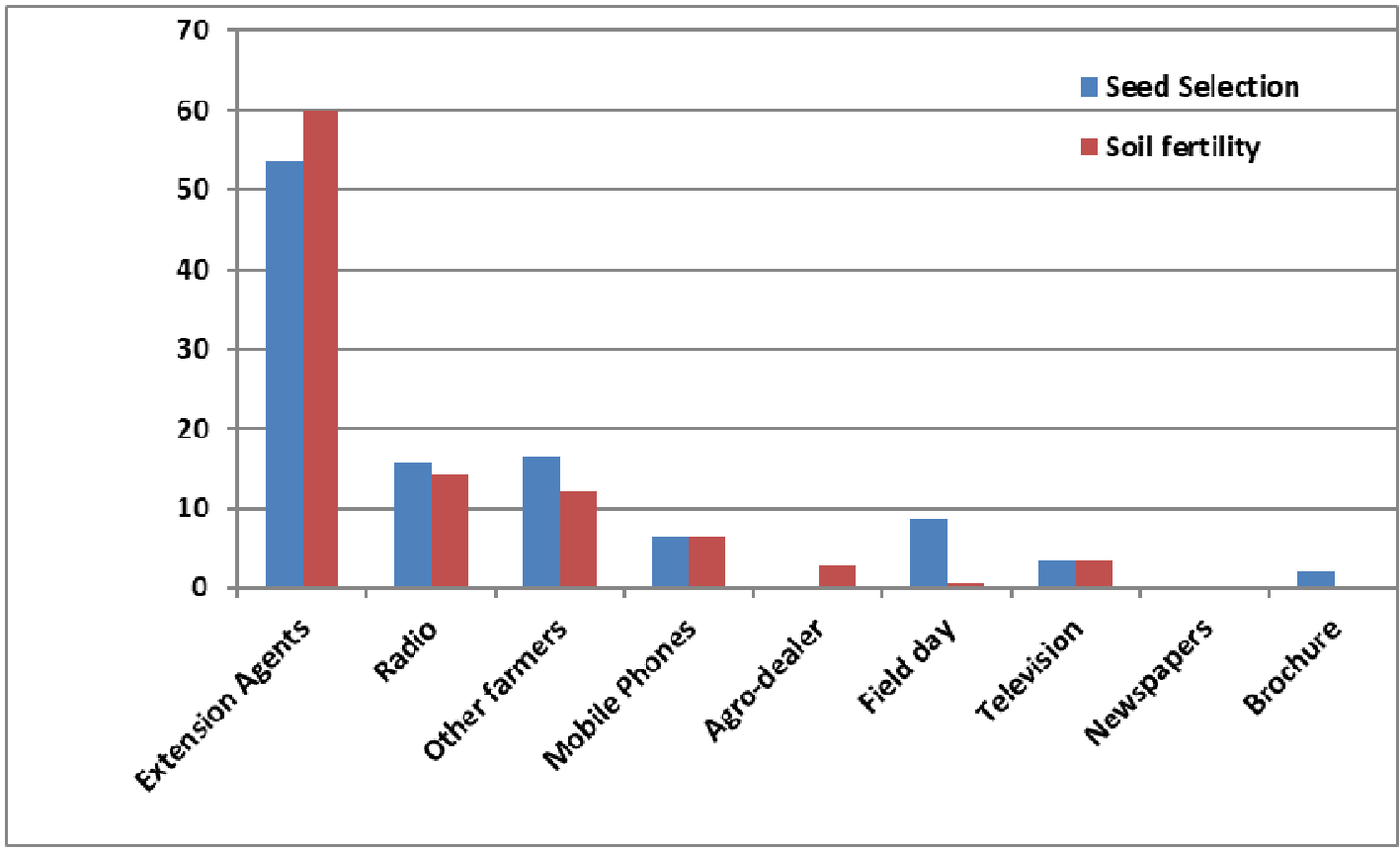

Figure 4: Distribution of Non-Participants according to the sources of information on GAPs (Nasarawan Buhari Village)

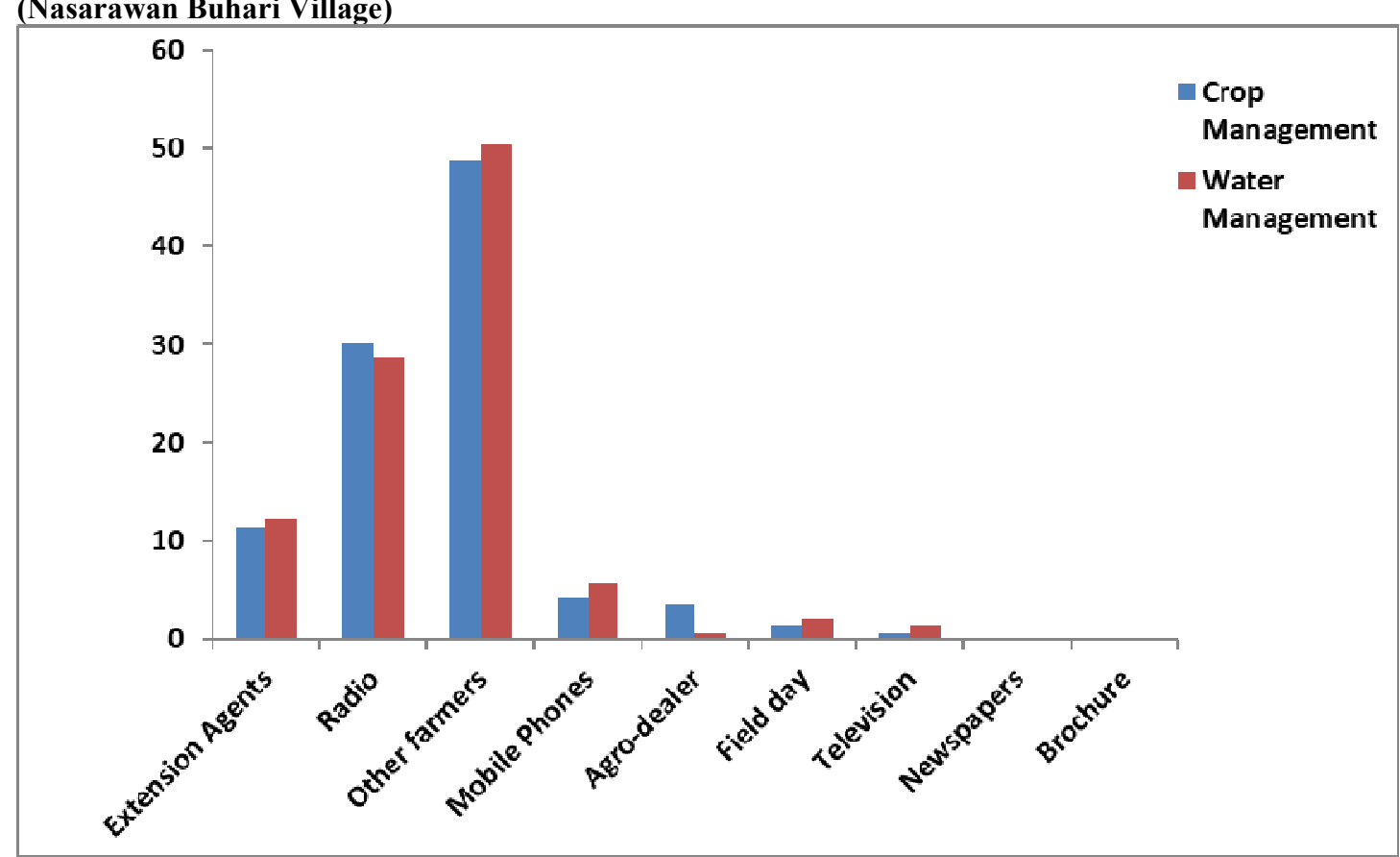




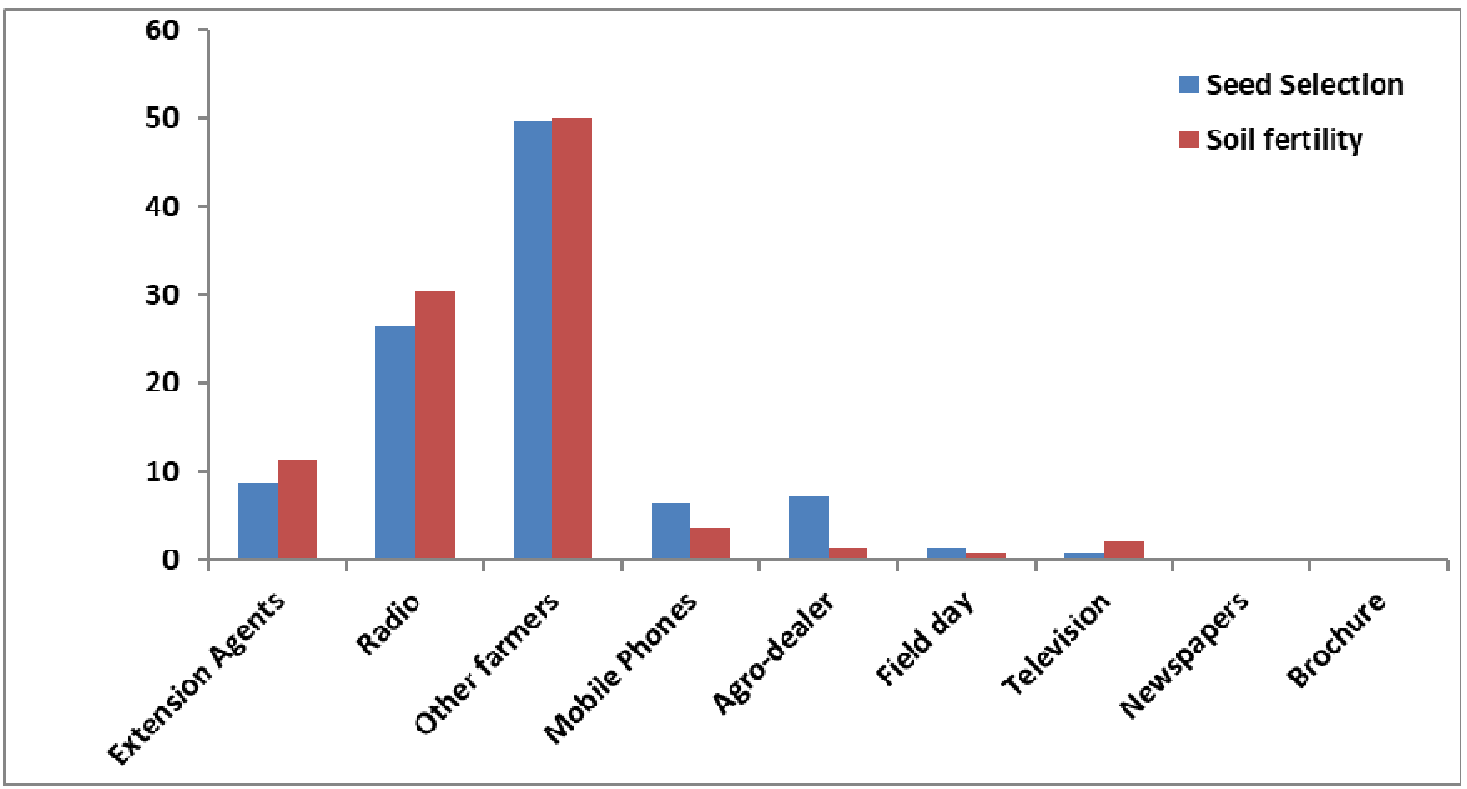

\subsection{Practice of Good Agricultural Practices among Smallholder farmers}

Respondents were asked to state their level of uptake of the stated GAPs. As shown in Table 3; the majority of the respondent indicated low levels of implementation of cropland management. Similarly, a significant proportion of respondents (39\%) specified low levels of appropriate water management on their farmland, while the result in Table 4 confirms that the practice of integrated pest management is extremely low among the respondents with $40 \%$ indicating low and $32 \%$ moderate implementation of the GAPs. The findings in table 4 also reveal that farmers indicated low levels of practice of integrated pest management; seed, crop selection and seeding production and soil fertility management at 40, 40 and 35\% respectively. This might be attributed to non-availability of smallholder farmers to procure essential inputs needed to sustainably increase their productivity which subsequently results in reductions in productivity and livelihoods among smallholder farmers in the adopted villages (Flenchtmann and Knihinicki 2002).

Table 4: Distribution of respondents according to practice of GAPs

\begin{tabular}{|c|c|c|c|c|c|}
\hline \multirow{2}{*}{$\begin{array}{l}\text { Agricultural } \\
\text { Production } \\
\text { Components }\end{array}$} & \multirow{2}{*}{$\begin{array}{l}\text { Very } \\
\text { High }\end{array}$} & \multicolumn{2}{|c|}{ Moderate } & \multicolumn{2}{|r|}{ Not } \\
\hline & & High & & Low & at all \\
\hline Crop Land Management & 16.1 & 21.4 & 24.2 & 34.0 & 4.3 \\
\hline Water Management & 9.3 & 16.4 & 31.1 & 39.7 & 3.5 \\
\hline Degraded lands Restoration & 9.3 & 12.1 & 32.2 & 40.0 & 6.4 \\
\hline Integrated Pest Management & & & & & \\
\hline Seed, Crop Selection & 10.7 & 12.9 & 31.4 & 40.0 & 5.0 \\
\hline and Seedlings Production 12.1 & 26.2 & 17.3 & 40.1 & 4.3 & \\
\hline Soil fertility Management 19.3 & 9.3 & 28.5 & 35.0 & 7.9 & \\
\hline
\end{tabular}

\subsection{Level of Extension Contact}

The mission of extension services is to provide research based information, educational programs and technologies on farmers needs which invariably provides an opportunity for transfer of skills, knowledge and accurate information which enables farmers to make an informed decision and facilitate adoption (Long and Sworzel 2007; Oladele 2010; Adesope et al. 2010). The distribution of respondents according to the number of extension visits to the Adopted Villages is presented in Figure x. Contact with extension agents provides channels by which farmers' problems are identified for research and play a significant role in the adoption of technologies (Adesiji et al. 2010; Ajani and Onwubuya 2013; Ainembabazi and Mugisha 2014). Table 4 reveals 
that just over one-third (34\%) of farmers in the adopted villages received extension visits once a month while $29 \%$ had extension contact during the raining season and $17 \%$ indicated that they do not receive extension visits. Furthermore, finding shows that the respondents who had more extensions visits have a higher level of GAPs implementation compare to their counterparts. This implies that role of extension services and accurate dissemination of information to the adoption of improved technologies cannot be underrated.

Figure 5: Distribution of respondents by extension contact (Nasarawan Buhari and Sakadadi Villages)

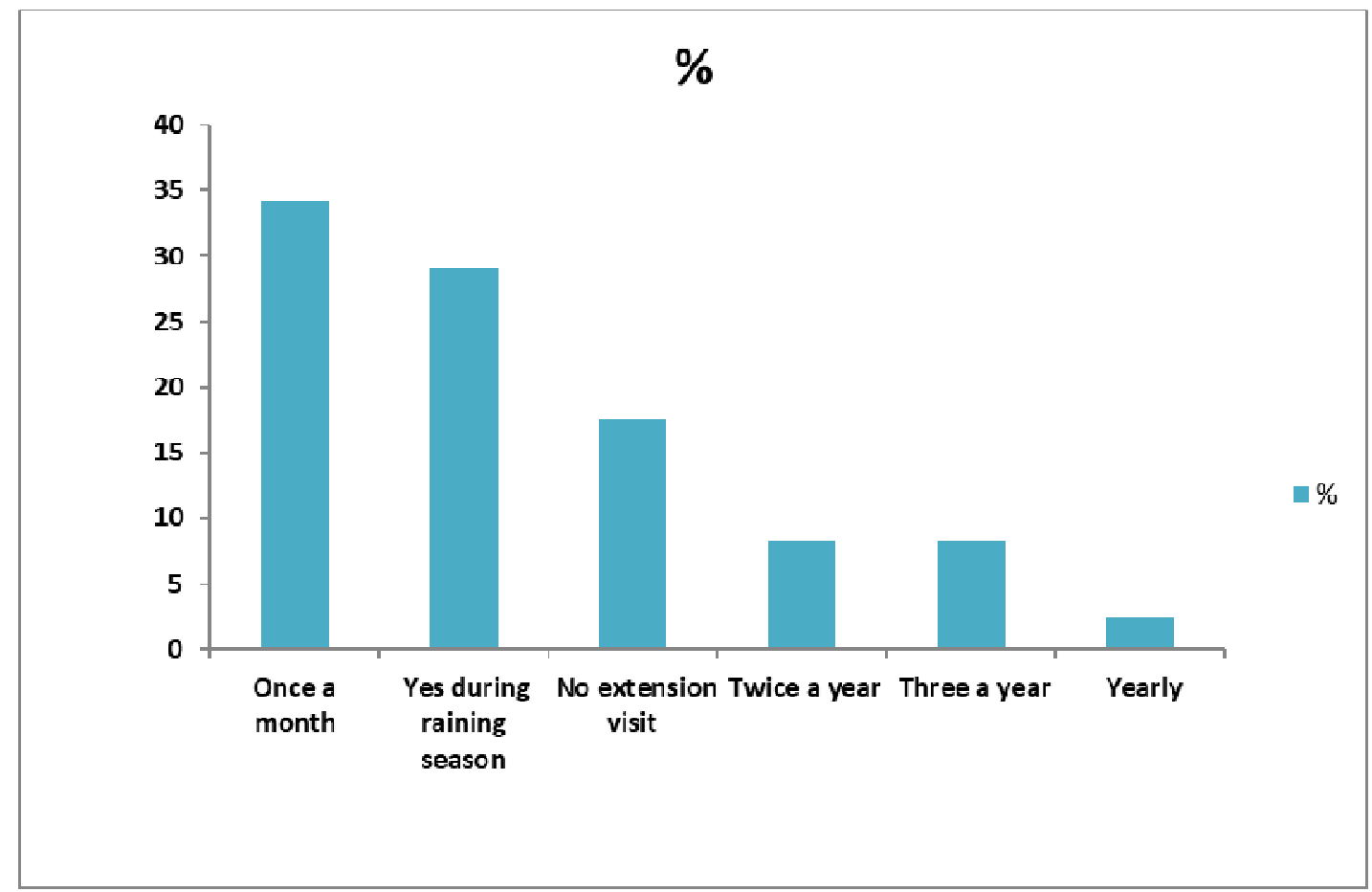

Table 5 shows that $26 \%$ of the respondents indicated a lack of fertilizers as the principal challenge they are facing, followed by inadequate capital $(20 \%)$ and poverty $(15 \%)$. Similarly, $10 \%$ of the respondents noted inadequate and unreliable rainfall as another prevailing problem confronting them in practicing GAPs.

Table 5: Factors influencing implementation of GAPs

Problems
Fercentage

Lack of fertilizers

Inadequate finance/capital

Poverty

80.8

Inadequate and unreliable rainfall

High cost of farm inputs

71.7

Poor market prices

61.6

Lack of irrigation facilities

53.3

High rate of pest and disease attack $\quad 52.5$

Low production hence little returns $\quad 50.8$

Illiteracy/lack of education $\quad 48.3$

Lack of technical know-how $\quad 43.3$

Inadequate labour $\quad 40.8$

Lack of portable water $\quad 39.2$

Infrastructural problem /land tenure $\quad 35.0$

Poor storage facilities $\quad 25.8$

*Multiple Responses 


\subsection{Conclusion}

This study, have revealed that $61 \%$ of the respondents in the study area were aware of the GAPs as conveyed to them by the extension officers from NAERLS, ABU, Zaria. The study also shows that the level of awareness of GAPs was very high. Similarly, out of nine sources of extension information for the accredited GAPs, four were most prominent among the respondents, namely, extension agents, radio, fellow farmers and mobile phones. This is in agreement with the study conducted by Fadiji et al (2005) who found out that, extension agents, radio, fellow farmers, and television were veritable media and sources of extension information in the rural areas. Also, Ayoade (2010) stated that rural farmers should be encouraged to seek extension information on recommendations and technologies through various extension sources at their disposal. Moreover, findings show that majority of the respondents (72\%) indicated low in the uptake and implementation of GAPs in the study area. The study also revealed that the respondents were facing with numerous prevailing challenges which inhibit them from implementing the identified GAPs, namely; lack of fertilizers, inadequate finance, extreme poverty, unreliable rainfall and cost of production among others. This is in agreement with the findings of Pongvinyoo et al (2014) among coffee farmers in Thailand, which stated that farmers still lacked farm input, knowledge and experience of GAPs and their conventional farming activities are often conflicting with the GAPs system. Also, FAO (2010) asserts that financial cost and specialized knowledge make implementation of GAPs such as water purification equipment or record-keeping technology more difficult for smallholder farmers and producers in developing countries. In the same vein, in a study conducted by Akkaya et al (2006) on GAPs and its implementation in Turkey, identified limitations over the fragmented structure of production area, lack of keeping records, lack of establishment of growers' organization in term of number and scale to expand widely GAP system. By and large, this study concluded that the main challenge to GAPs among smallholder farmers is to put the system into practice more widely.

\subsection{Recommendations}

The study recommends that the Federal Ministry of Agriculture should provide more funds for NAERLS in order to intensify its efforts in the pilot communities' development projects and expanded its Adopted Village concepts to other parts of the country which invariably will create more awareness of the GAP system among rural communities. It also recommends collaboration between government and private sectors, such that the implementation of GAP becomes part of the private sector standard. If successful, this collaboration might encourage smallholder farmers to be more aware and make better informed decisions which encourages comprehensive implementation of the system. Furthermore, effort should be made by all tiers of Government towards encouraging smallholder farmers to practice the GAP system by providing farm inputs and irrigation system for the rural community. Extension services should embark on massive public enlightenment campaigns and mass information mobilization in the rural communities across the nation.

\section{References}

Adedipe, N.O., Okuneye, P.A. and Ayinde, I.A. (2004).The relevance of local and indigenous knowledge for Nigerian agriculture. Paper presented at the International Conference on Bridging Scales and Epistemologies: Linking Local Knowledge with Global Science in Multi-scale Assessments. Alexandria, Egypt, 16-19 March 2004

Adesiji, G.B, Akinsorotan, A.O. and Omokore, D.F. (2010). Farmers' Assessment of Extension Services in Ogun State, Nigeria, Journal of Agricultural \& Food Information, 11:2, 143-156,

Agricultural Research Council of Nigeria, ARCN (2008).Implementation of the Adopted Villages and Agricultural Research Outreach Centres (AROCs) by the National Agricultural Research Institutes (NARIs) and Federal Colleges of Agricultures (FCAs).A Draft Document. July, 2008

Ainembabazi, J.H. and Mugisha, J. (2014). The Role of Farming Experience on the Adoption of Agricultural Technologies: Evidence from Smallholder Farmers in Uganda, Journal of Development Studies, 50:5, 666-679

Ajani, E. N. andOnwubuya, E. A. (2013). Constraints to Effective Communication Among Extension Agents in Anambra State, Nigeria, Journal of Agricultural \& Food Information, 14:1, 18-25

Akkaya, F., Yalcin, R. and Ozkan, B. (2006). Good Agricultural Practices and Its Implementation in Turkey, ACTA Horticulture.

Ajani, E.N. and Igbokwe, E.M. (2014).A Review of Agricultural Transformation Agenda in Nigeria: The Case of Public and Private Sector Participation, Journal of Agriculture and Environmental Management.3:5, 238-245 
Akinola, M.O., Odu, M.E. and Baiyegunhi, L.J.S. (2013). The Adopted Village Project and Farm Income of Beneficiary Households in Kaduna State, Nigeria,Journal of Stud Tribes Tribals, 11:2, 121-126

Ali, J. (2014): Adoption of innovative agricultural practices across the vegetable supply chain, International Journal of Vegetable Science, 1-10

Arokoyo, T. (2005).ICTs Application in Agricultural Extension Service Delivery.In: Adedoyin F.S. (Ed) Agricultural Extension in Nigeria.1st edition. Ilorin: AESON, Pp 245-251.

Ayoade, A.R. (2010). Effectiveness of Information Sources on Improved Farm Practices among Cowpea Farmers in Oyo State. Global Journal of Human Social Science, 10:1, 39-45

Bewket, W. (2007) Soil and water conservation intervention with conventional technologies in North-western highlands of Ethiopia: Acceptance and adoption by farmers. Land Use Policy, 2, 23-35.

Chowa, C., Garforth, C. and Cardey, S. (2013). Farmer Experience of Pluralistic Agricultural Extension, Malawi, Journal of Agricultural Education and Extension, 19:2, 147-166

Dhillon, B. S., Kataria, P.andDhillon, P. K. (2010). National Food Security vis-a-vis sustainability of agriculture in high crop productivity regions. Current Science, 98, 33-36

Fadiji, T.O., Atala, T.K. and Voh, J.P. (2005).Sources and use of Extension Information among maize farmers in rural northern Nigeria.Journal of Agriculture and Social Research, 5:1, 11-17

FAO. (2010). "Towards the future we want, end hunger and make the transition to sustainable Agricultural and food systems". Rome. www.fao.org/docrep/015/an894e/an894e00.pdf Retrieved 2 October, 2015.

Federal Government of Nigeria (FGN) (2008)."National Food Security Program" Federal Ministry of Agriculture and Water Resources, Abuja, Nigeria.

Gahukar, R.T. (2011) Food Security in India: The Challenge of Food Production and Distribution, Journal of Agricultural \& Food Information, 12:4, 270-286,

Gani, B. S. and Adeoti, A. I. (2011).Analysis of market participation and rural poverty amongfarmers in Northern part of Taraba State, Nigeria.Nigeria Journal of Economics, 2, 23-26.

IFAD. (2013). Smallholders, food security and the environment: Rome, International Fund for Agricultural Development (IFAD). http://www.ifad.org/climate/resources/smallholders_report.pdf (retrieved 28 October 2015).

Kalungu J.W, Filho, W. L. and Harris, D. (2013). Smallholder Farmers' Perception of the Impacts of Climate Change and Variability on Rain-fed Agricultural Practices in Semi-arid and Sub-humid Regions of Kenya, Journal of Environment and Earth Science, 3:7, 129-140.

Lefebvre, M., Espinosa, M., Paloma, S.G., Paracchini, M.L., Piorr, A. and Zasada, I. (2015). Agricultural landscapes as multi-scale public good and the role of the Common Agricultural Policy, Journal of Environmental Planning and Management, 58:12, 2088-2112,

Long, J L. and Swortzel, K A. (2007).Factors influencing individual job performance of Extension agents in the Mississippi State University Extension Service.Proceedings of the American Association for Agricultural Education, 4: 29-40.

Lowder, S.K., Skoet, J. and Singh, S. (2014). What do we really know about the number and distribution of farms and family farms worldwide? Background paper for The State of Food and Agriculture 2014. ESA Working Paper No. 14-02. Rome, FAO. 
Montagne, D., Cornu, S., Bourennane, H., Baize, D., Ratié, C. and King, D. (2007). Effect of Agricultural Practices on Trace-Element Distribution in Soil, Communications in Soil Science and Plant Analysis, 38:3, 473491

Mustapha, S. B., Gwary, M.M., Nuhu, H.S. and Samaila, P.A. (2012).Assessment of the Effectiveness of Lake Chad Research Institute "Adopted Villages Scheme" in the Dissemination of Improved Farm Technologies in Borno State, Nigeria,International Journal of Science and Technology, 12:2, 837-842.

NAERLS, (2011). Annual Report (Ahmadu Bello University, Zaria, Nigeria: National Agricultural Extension and Research Liaison Services Press, 2011).

Nagayets, O. (2005). Small Farms: Current status and key trends Information brief prepared for the future of small farms research workshop Wye College, June 26-29.

National Population Commission (NPC) (2006): National Population and Housing Survey.NationalPopulation Commission, Abuja, Nigeria.

Nkala, P., Mango, N. and Zikhali, P. (2011). Conservation Agriculture and Livelihoods of Smallholder Farmers in Central Mozambique, Journal of Sustainable Agriculture, 35:7, 757-779,

Nwafor, M. (2008). Literature review of development targets in Nigeria. Ibadan: International Institute of Tropical Agriculture, Retrieved 5 October, 2015.

Oji-Okoro, I. (2011). Analysis of the contribution of Agricultural Sector in the Nigeria Economic Development. World Review of Business Research, 1, 191-200.

Okunade, O.E. (2006). Factors Influencing Adoption of Improved Farm Practices Among Women Farmers in Osun State, Nigeria, Journal of Human Ecology, 19:1, 45-49

Oladele, O.I. and Tekena, S.S. (2010).Factors influencing agricultural extension officers' knowledge on Practice and Marketing of Organic Agriculture in North West Province, South Africa, Life Science Journal,7:3, 144-156

Olajide, B. R. (2011). Assessment of farmers' access to agricultural information on selected food crops in Iddo District of Oyo State, Nigeria. Journal of Agricultural \& Food Information, 12:(3-4), 245-267.

Onyekwelu, J.C; Olusola, J.A., Stimm, B., Mosandl, R. and Agbelade, A.D. (2015). Farm-level tree growth characteristics, fruit phenotypic variation and market potential assessment of three socio-economically important forest fruit tree species, Forests, Trees and Livelihoods, 24:1, 27-42

Osebeyo, S.O. and Aye, G.C. (2014). Transaction costs and marketing decision: a case study of smallholder tomato farmers in Makurdi, Nigeria, Urban, Planning and Transport Research, 2:1, 333-340,

Paudel, G.S. and Thapa, G.B. (2004) Impact of social, institutional and ecological factors on land management practices in the mountain watersheds of Nepal. Applied Geography 24, 35-55.

Poole, N.D. and Lynch, K. (2003). Agricultural market knowledge: Systems for delivery of a private and public good, Journal of Agricultural Education and Extension, 9:3, 117-126

Pongvinyoo, P., Yamao, M. and Honson, K. (2014).Factors Affecting the Implementation of Good Agricultural Practices (GAPs) among Coffee Farmers in chumphon Province, Thailand.American Journal of Rural Development, 2:2, 34-39

Sennuga, S.O. (2012).The Application of Information and Communication Technologies to Small-scale Agriculture in Nigeria.(Unpublished Master's Thesis).University of Reading, Reading, United Kingdom.

Stevenson, J. R., Serraj, R., and Cassman, K. G. (2014).Evaluating conservation agriculture for small-scale farmers in Sub-Saharan Africa and South Asia.Agriculture, Ecosystems \& Environment, 187, 1-10 
Umar, B.B., Aune, J.B., Johnsen, F.H. \&Lungu, I.O. (2012). Are Smallholder Zambian Farmers Economists? A Dual-Analysis of Farmers' Expenditure in Conservation and Conventional Agriculture Systems, Journal of Sustainable Agriculture, 36:8, 908-929,

Vermeulen, S.J., Campbell, B.M. and Ingram, J.S.I. (2012).Climate Change and Food Systems.Annual Review of Environment and Resources, 37, 195-222.

World Bank (2008). World Development Report 2008: Agriculture for Development. World Bank, Washington, DC.siteresources.worldbank.org/.../WDROver2008-ENG.pdf Retrieved 2 October, 2015

Wright, H., Vermeulen, S., Laganda, G., Olupot, M., Ampaire E. and Jat, M.L. (2014). Farmers, food and climate change: ensuring community-based adaptation is mainstreamed into agricultural programmes, Climate and Development, 6:4, 318-328

Yila, O.M. and Thapa, G.B. (2008). Adoption of agricultural land management technologies by smallholder farmers in the Jos Plateau, Nigeria, International, Journal of Agricultural Sustainability, 6:4, 277-288 